\title{
Teaching and Learning Strategies of Oral Histology Among Dental Students
}

\author{
Estrategias de Enseñanza y Aprendizaje de Histología Oral en Estudiantes de Odontología
}

\author{
Salma Abubaker Abbas Ali \& Sadatullah Syed
}

ALI, S. A. A. \& SYED, S. Teaching and learning strategies of oral histology among dental students. Int. J. Morphol., 38(3):634-639 2020 .

SUMMARY: Dental education is in a continuous state of development to adapt to the changing learning strategies of the millennial students. The introduction of electronic learning resources (ELR) is a good example, which has added immense value to the traditional methods of teaching oral histology. The main purpose of the study was to analyze the dental students' perception of learning oral histology the way it was taught. A pre-approved questionnaire survey was electronically distributed to 129 students who had completed the oral histology course. The majority of the students viewed oral histology course to be difficult and irrelevant to their dental career. Similarly, most of them preferred studying alone and used ELR in place of books and atlases. More than three quarters believed using a microscope in practical training sessions will make the oral histology course easier and more interesting. The results of this study will be used to formulate recommendations to be implemented in oral histology course.

KEY WORDS: Oral Histology; Oral biology; Dental Education; Dental students; Course evaluation.

\section{INTRODUCTION}

The consistent issue in reference to dental pedagogy is that it is not exempted from vicissitude. The teaching strategies can be as ideal as the situation within which they are deployed. This is mainly because academic situations are dictated by volatile factors from the scientific and nonscientific forces. Dental education like any other education system is in a living state undergoing continuous development and progression. For example, the use of electronic teaching methods (Mattheos et al., 2008), software applications (Ciampa, 2014), online learning management systems (Ruiz et al., 2006) and mobile devices (Doyle et al., 2014) have significantly added worth to the traditional methods in teaching histology (Campbell et al., 2010). Utilizing digital technology has enabled course managers, especially those for oral histology, to effectively modify teaching strategies, allowing the millennial students to adapt to the ever-changing learning set-up (Hortsch, 2013).

Histology is the branch of medical science concerned with the microscopic anatomy of cells and tissues of living organisms that are studied by microtomic sectioning, staining, and assessment of microstructures under the microscope. Oral histology, a subdivision of histology is an essential element of oral biology, an important subject in the basic sciences group taught early in the dental curriculum. This is so because it comprises of interdisciplinary matter that is related to several dental specialties. Though the knowledge of anatomy and histology are known to be important for a dental practice, dental students are known to consider oral histology as less relevant for their career and more challenging to learn (Johnson et al., 2015). In-depth knowledge of oral histology supports a better understanding of pathological events of the orofacial region which in turn helps in diagnosing and treating such events.

With the knowledge base of oral histology expanding and learning strategies evolving, it is imperative to validate the prevalent training and learning methods, and examine the traditional methods whether they need to be disregarded or modified to optimize the overall training and learning process. Therefore, the main objective of this study was to investigate the students' perception of learning oral histology the way it was taught. We focused on the choices students made regarding their oral histology course while selecting learning resources, and their study habits. An anonymous perception survey adapted from the University of Michigan 
Institutional Medical Review Board questionnaire was applied to a group of students who have completed the Oral histology course. The survey was conducted electronically with a Likert scale consisting of 16 questions with 5 options.

\section{MATERIAL AND METHOD}

Components of oral histology syllabus. Bachelor of Dental Surgery at King Khalid University is a six-year program that consists of basic science courses taught in the first three years and then proceeds on to involve clinical courses for the remaining three years. Oral histology is taught in the third year of the program and is divided into didactic lectures and practical sessions. Two lectures and one practical session that corresponds to four hours of weekly teaching are covered by three instructors throughout the 14 weeks of the course. The curriculum includes embryology of the orofacial region, in addition to tooth development, histological aspects of dental hard tissues, periodontium, oral mucosa, eruption, shedding and salivary glands. The practical sessions involve virtual histology slide presentations through Microsoft PowerPoint and histology manual based practical activity. Attending $80 \%$ of the lectures and practical sessions are compulsory to be eligible to appear for the final exams. Learning resources in the form of textbooks, course coordinator approved pdf material and Microsoft PowerPoint presentations are available through the library and online Blackboard system. Assessment methods include multiple choice question exams, e-learning assignment, identification of virtual slides and an oral exam.

The questionnaire, study samples, and statistical analysis. This randomized, cross-sectional study utilized a pre-approved questionnaire survey by the institutional review board vide number SRC/REG/2015-2016/47. The online questionnaire was based on the University Of Michigan questionnaire with minor modifications to suit the targeted students. The questionnaire comprised of sixteen questions

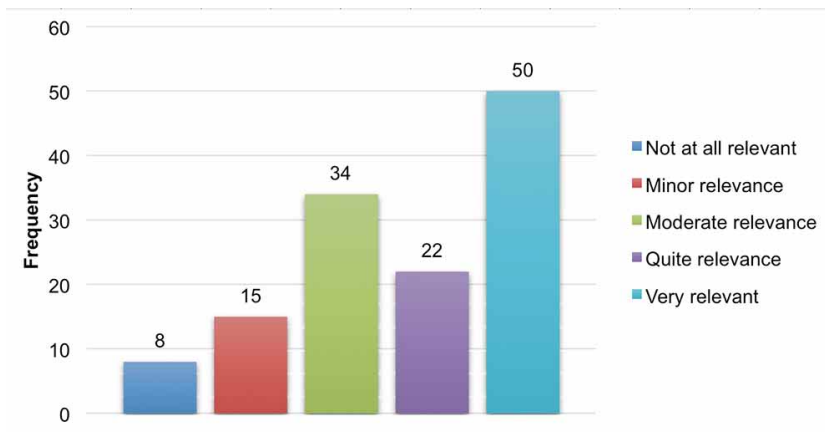

Fig. 1. The relevance of oral histology for general dental practitioners. Response to question 1. that were reviewed by one oral histology instructor and two final year students who suggested minor modifications. 129 students who had completed the oral histology course at King Khalid University College of Dentistry voluntarily participated in the study. The survey questions focused on probing areas of learning oral histology, students' study habits, and the preferred learning resources. Descriptive statistical analyses of the responses were carried out in SPSS version 21.

\section{RESULTS}

The relevance of oral histology in general dental practice. All the responses were registered on a five-point Likert scale with scores ranging between 1 and 5. The responses for question 1 were scored between 'not relevant at all' (score of 1) to 'very relevant' (Score 5). Fifty participating students viewed histology as 'not relevant at all' to their career as a general dental practitioner, and only 8 students scored oral histology as 'very relevant'. Likewise, 22 students viewed oral histology as 'quite relevant', and the remaining 34 perceived it as 'moderately relevant' for dental practice (Fig. 1).

Level of difficulty of oral histology course. The next question from the questionnaire focused on knowing the level of difficulty of oral histology course among students before starting the course and after completing it. The scores ranged between 'very difficult' to 'very easy' as shown in Table I. Before starting the course $36.4 \%$ students perceived oral histology as 'somewhat easy', $24 \%$ anticipated it to be 'very easy', $33.3 \%$ were neutral and could not decide whether it was easy or difficult, while $4.7 \%$ thought it to be 'somewhat difficult', and only 2 students accounting for $1.6 \%$ considered it to be 'very difficult'. After completing the course the perception of students shifted, as almost $29.5 \%$ of students scored oral histology as 'somewhat difficult', and only 8 students which accounts for $6.2 \%$ of the participants believed oral histology as a 'very easy' course. More than a quarter (34\%) remained neutral, reporting the course to be 'neither easy nor difficult' after completing it.

Study habits related to oral histology course. Questions four and five having a score range of never, rarely, don't know, frequently and always, focused on eliciting how often the students studied oral histology and whether they preferred studying alone or in groups (Table II). $25.6 \%$ of students reported 'never' studying with others while $34.9 \%$ 'rarely' study with others. $27.1 \%$ of them 'always' study alone, 8.5 $\%$ 'frequently' study alone and the remaining $10.9 \%$ 'never' study on their own. 
Table I. Level of difficulty of Oral Histology course. Response to questions 2 and 3.

\begin{tabular}{|c|c|c|c|c|c|c|}
\hline & & $\begin{array}{l}\text { Very } \\
\text { difficult }\end{array}$ & $\begin{array}{l}\text { Somewhat } \\
\text { difficult }\end{array}$ & $\begin{array}{l}\text { Neither difficult } \\
\text { nor easy }\end{array}$ & Somewhat easy & Very easy \\
\hline Q.2 & $\begin{array}{l}\text { How difficult do you evaluate } \\
\text { oral histology as a study } \\
\text { subject BEFORE starting } \\
\text { histology lessons? }\end{array}$ & $2(1.6 \%)$ & $6(4.7 \%)$ & $43(33.3 \%)$ & $47(36.4 \%)$ & $31(24 \%)$ \\
\hline Q.3 & $\begin{array}{l}\text { How difficult do you evaluate } \\
\text { oral histology as a study } \\
\text { subject AFTER completing } \\
\text { histology lessons? }\end{array}$ & $11(8.5 \%)$ & $38(29.5 \%)$ & $44(34.1 \%)$ & $28(21.7 \%)$ & $8(6.2 \%)$ \\
\hline
\end{tabular}

Table II. Study habits related to oral histology course. Response to questions 4 and 5.

\begin{tabular}{llccccc}
\hline & & Never & Rarely & Moderately & Frequently & Always \\
\hline$Q .4$ & $\begin{array}{l}\text { How often do you study } \\
\text { oral histology by yourself? }\end{array}$ & $14(10.9 \%)$ & $24(18.6 \%)$ & $45(34.9 \%)$ & $11(8.5 \%)$ & $35(27.1 \%)$ \\
Q.5 & $\begin{array}{l}\text { How often do you study } \\
\text { oral histology with others? }\end{array}$ & $33(25.6 \%)$ & $45(34.9 \%)$ & $34(26.4)$ & $11(8.5 \%)$ & $6(4.7 \%)$ \\
\hline
\end{tabular}

Table III. Study habits related to oral histology course. Response to questions 8 and 9.

\begin{tabular}{|c|c|c|c|c|c|c|}
\hline & & Never & Rarely & Moderately & Frequently & Always \\
\hline Q.8 & $\begin{array}{l}\text { How often do you } \\
\text { attend oral histology } \\
\text { classes in person }\end{array}$ & $6(4.7 \%)$ & $13(10.1 \%)$ & $31(24 \%)$ & $28(21.7 \%)$ & $51(39.5 \%)$ \\
\hline Q.9 & $\begin{array}{l}\text { How often do you } \\
\text { attend oral histology } \\
\text { laboratories in person }\end{array}$ & $8(6.2 \%)$ & $22(17.1 \%)$ & $29(22.5 \%)$ & $31(24 \%)$ & $39(30.2 \%)$ \\
\hline
\end{tabular}

Table IV. Learning resources for oral histology course. Response to questions 15 and 16.

\begin{tabular}{|c|c|c|c|c|c|}
\hline & & \multicolumn{2}{|c|}{ No } & \multicolumn{2}{|r|}{ Yes } \\
\hline \multirow[t]{3}{*}{ Q.15 } & Do you thin $\mathrm{k}$ using microscopes would have made & \multicolumn{2}{|c|}{$18(14 \%)$} & \multicolumn{2}{|c|}{$111(86 \%)$} \\
\hline & & Strongly Agree & Agree & Disagree & Strongly \\
\hline & & & & & Disagree \\
\hline Q.16 & $\begin{array}{l}\text { Do you thin } k \text { having more than one inst ructor for the } \\
\text { course leads to a better outcome of the learning process }\end{array}$ & $47(36.4 \%)$ & $52(40.3 \%)$ & $22(17.1 \%)$ & $8(6.2 \%)$ \\
\hline
\end{tabular}

In response to question six $58.1 \%$ students don't seem to have had any experience with oral histology in their previous academic years. Nearly half of the students (43.4 $\%)$ reported changing their study habits as the course progressed during the semester.

On a grading scale between 'Always' and 'Never for questions 8 and 9 (Table III), $39.5 \%$ of students reported 'Always' attending oral histology classes in person, and 4.7 $\%$ of students 'Never' attending classes in person. For practical activities, only $30.2 \%$ 'Always' attend oral histology practical sessions.

Learning resources for oral histology course. Responses to question 11 revealed more than half $(40.3+19.4=59.7 \%)$ of the participating students 'never' or 'rarely' used oral histology textbooks or atlases. A meager $2.3 \%$ 'always' used textbooks as a learning resource (Fig. 2). Similarly, more than half $(56.6 \%)$ don't have a single preferred textbook as a learning resource. However, $34.4 \%$ referred to Ten Cate's Oral Histology as their reference of choice. In comparison to textbooks, close to half $(21.7+21.7=43.4 \%)$ of the students reported 'always or frequently' using the course coordinator approved pdf files as study material (Fig. 3). A very similar percentage of students (42.5\%) 'always' or 'frequently' used electronic learning resources (ELR) such as online videos and slides (Fig. 4).

$86 \%$ of students agreed that using a microscope in practical training sessions would have made studying oral histology easier and more interesting. Three quarter (76.7 $\%$ ) of the participating students think having more than one instructor for the course leads to a better outcome of the learning process. Only $6.2 \%$ think otherwise (Table IV). 


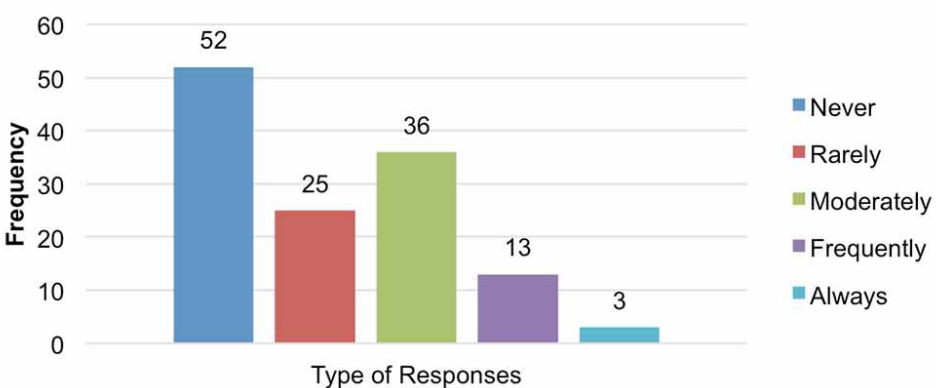

Fig. 2. Learning resources for Oral histology course (Use of textbooks). Response to question 10.

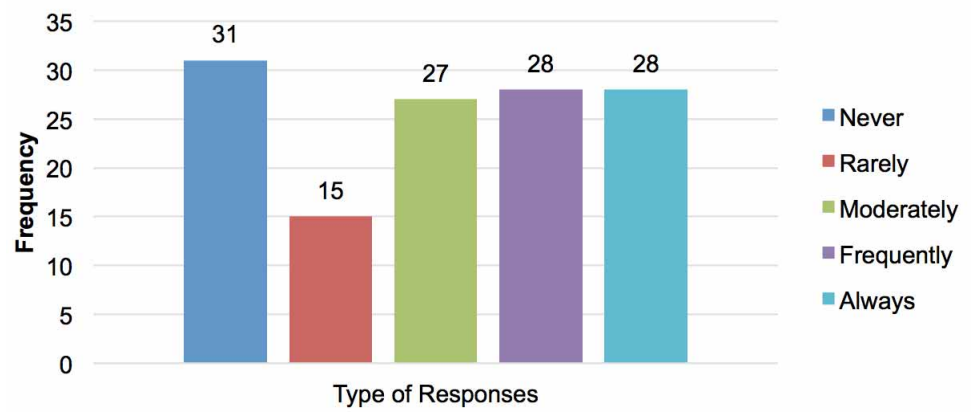

Fig. 3. Learning resources for Oral histology course (Use of pdf files). Response to question 11 .

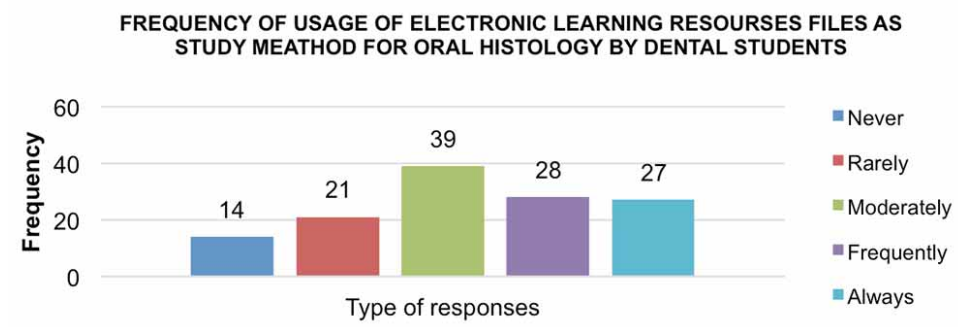

Fig. 4. Learning resources for Oral histology course (Use electronic learning resources). Response to question 12.

\section{DISCUSSION}

According to the students, oral histology is a difficult subject and less relevant to their prospective dental career. Similar results were reported by Johnson et al., where they compared the learning strategies of dental students and medical students. This can be an ominous sign for the instructors of the oral histology course and the courses that are related to it. Information in the oral histology course forms the foundation for clinical dental science and an important prerequisite for oral diagnosis and treatment planning. It is a complex content base branch of basic sciences with diverse subjects (including anatomy, histology, and embryology) that are repeated during the dental curriculum (Anyanwu, 2014). The relevance of oral histology, when made clear to students at an early stage will strengthen the concepts of pathology and diagnosis of oral conditions. This should be initiated well before they take up oral histology and general histology courses. One of many things that can be done to instill the significance of oral histology is to relate each histologic topic with a clinical or laboratory situation similar to what was suggested by Norman (Norman, 2009) to enhance transfer. By applying the teaching strategies proposed by Norman, like, inserting a concept in a problem, active problem solving and using routine analogies the importance of oral histology can be improved while enhancing transfer.

Alternatively, the syllabus can be modified to combine the oral histology part of one topic along with the oral pathology and oral medicine part of the same topic. For example, in oral histology, the lectures of development and histology of enamel can precede the pathological conditions of enamel followed by the diagnosis and treatment of them. This should keep the relevance and the interest of oral histology high among the students. The concept of combining disciplines through the integration of histology topics for dental students was proposed by Dorothy et al. (Burk et al., 2013) in their survey study of dental faculty teaching histology and embryology in North American Dental Schools. Another example of combining methods to teach neuro-anatomy leading to a better learning experience is provided by Chariker et al. (2011). Similarly, Tayyem et al. (2019) highlighted the advantages of combining techniques in teaching anatomy to undergraduate medical students.

The students considered oral histology to be easy at the beginning of the course, however, their perception changed when they completed it. This, in addition to the relatively low interest in attending lectures and practical sessions stems from the fact that they do not consider oral histology to be relevant enough for their future. Given the survey responses, it is deemed appropriate to presume that these students would not enroll if oral histology were an elective course. In sync with the global millennial student's mindset (Zhang \& Nunamaker, 2003), the students favored ELR (Gambo et al., 2017) to traditional books and atlases (Salajan \& Mount, 2008). This too, explains the lack of interest in attending lectures and practical sessions, as the desire to learn during the teaching sessions, is far 
less than to gain from online sources. The majority of our students showed interest in ELR because they have easy access to learning tools through Blackboard $\odot$ learning management system, and other digital material available on the internet. The use of technology for learning dental health sciences is a process that needs understanding and adaptation, which the millennials are more adept at (Ciampa, 2014; Dennen \& Hao, 2014). They have shown preference to 'ubiquitous learning' in which imbibing knowledge is dispersed in time and space (Burbules, 2012). Several studies (Dennen \& Hao; Janssen et al., 2015) have shown similar student interest in ELR while other studies like Johnson et $a l$.) reported less use of oral histology course website.

Physical presence during teaching sessions and practical experience of the subject matter is bound to make the relevance of the course more clear to the majority. One unexpected aspect of learning histology pointed out by the students was that they showed interest in using histological slides and compound microscope for their practical sessions in place of the currently used virtual histological pictures projected through PowerPoint presentations. Several studies for over two decades have emphasized the benefits of the transition from light to virtual microscopy in teaching histology (Cotter, 2001; Harris et al., 2001; Weaker \& Herbert, 2009). This stark difference in preference substantiates the fact that students can have different priorities of learning in different set-ups. In the current curriculum plan, students get to use microscopes for oral pathology courses only and one of the big takeaways of this study is to recommend the course managers to introduce the use of microscopes in the oral histology practical training sessions too.

Largely, our sample of students preferred to study alone than in groups, which is in contrast to the findings of Johnson et al. This way they can avoid distractions, stay focused, maintain concentration level and evade negative perceptions about the study subject that might come through in a group study scenario (Mattheos et al.). Uninterrupted study periods and personalized time management are the two main advantages of studying alone. On the other hand, those who prefer to study in groups will take advantage of the motivation created by enthusiastic members, a diverse understanding of the subject can make the study process easy, and fun-filled.

\section{CONCLUSIONS}

Students of our study perceive oral histology to be a difficult course and irrelevant to their future career as dental practitioners. This is considered as a key finding of the study and the most plausible extrapolation of this finding seems to be the lack of detailed clinical correlation of histology topics with real-time pathological situations. This is thought to be a reflection on the students' level of interest leading to a relatively low attendance rate. Being true to their millennial values, the students preferred studying alone, using ELR such as PowerPoint presentations and course coordinator approved pdf material. The results of this study will be used as evidence for recommendations to course coordinators of oral histology and dental program managers at the University. These results point towards the necessity of improving teaching strategies and curriculum in context to the delivery of oral histology and other courses that are based on it. The main recommendations put forward are as follows.

1. Integrate and deliver topics of oral histology, oral pathology, and oral medicine courses together, to make the syllabi topic-based rather than discipline-based.

2. Adding pathological and clinical cases to the practical curriculum to emphasize the clinical scope of the course and its relevance to the dental practice.

3. The traditional method of teaching through histological glass slides and the use of a compound microscope to be brought back for practical sessions.

4. Repeat the survey every two years to close the evaluationrecommendations-implementation-evaluation loop.

ALI, S. A. A. \& SYED, S. Estrategias de enseñanza y aprendizaje de histología oral en estudiantes de odontología. Int. J. Morphol., 38(3):634-639, 2020.

RESUMEN: La educación dental se encuentra en un estado de desarrollo continuo para adaptarse a las cambiantes estrategias de aprendizaje de los estudiantes milenios. La introducción de recursos de aprendizaje electrónico (RAE) es un buen ejemplo, el cual ha agregado un valor importante a los métodos tradicionales de enseñanza de histología oral. El objetivo principal del estudio fue analizar la percepción de los estudiantes de odontología de aprender histología oral de la forma en que se enseñó. Una encuesta de cuestionario preaprobada se distribuyó electrónicamente a 129 estudiantes que habían completado el curso de histología oral. La mayoría de los estudiantes consideraron que el curso de histología oral era difícil e irrelevante para su carrera dental. Del mismo modo, la mayoría de ellos preferían estudiar solos y usaban RAE en lugar de libros y atlas. Más de las tres cuartas partes creen que usar un microscopio en sesiones de capacitación práctica, permitiría que el curso de histología oral sea más fácil e interesante. Los resultados de este estudio se utilizarán para formular recomendaciones que se implementarán en el curso de histología oral.

PALABRAS CLAVE: Histología oral; Biología oral; Educación dental; Estudiantes de odontología; Evaluación del curso 


\section{REFERENCES}

Anyanwu, E. G. Anatomy adventure: a board game for enhancing understanding of anatomy. Anat. Sci. Educ., 7(2):153-60, 2014.

Burbules, N. C. Ubiquitous learning and the future of teaching. Encount. Theory Hist. Educ., 13:3-14, 2012.

Burk, D. T.; Lee, L. M. \& Lambert, H. W. Embryology and histology education in North American dental schools: the Basic Science Survey Series. J. Dent. Educ., 77(6):744-56, 2013.

Campbell, G.; Demetriou, L. A. \& Arnett, T. R. Virtual histology in the classroom and beyond. Med. Educ., 44(11):1124-5, 2010.

Chariker, J. H.; Naaz, F. \& Pani, J. R. Computer-based learning of neuroanatomy: a longitudinal study of learning, transfer, and retention. J. Educ. Psychol., 103(1):19-31, 2011.

Ciampa, K. Learning in a mobile age: an investigation of student motivation. J. Comput. Assist. Learn., 30(1):82-96, 2014.

Cotter, J. R. Laboratory instruction in histology at the University at Buffalo: recent replacement of microscope exercises with computer applications. Anat. Rec., 265(5):212-21, 2001.

Dennen, V. P. \& Hao, S. Intentionally mobile pedagogy: the M-COPE framework for mobile learning in higher education. Technol. Pedagog. Educ., 23(3):397-419, 2014.

Doyle, G. J.; Garrett, B. \& Currie, L. M. Integrating mobile devices into nursing curricula: opportunities for implementation using Rogers' Diffusion of Innovation model. Nurse Educ. Today, 34(5):775-82, 2014.

Gambo, J. M.; Bahreman, N. T.; Watties-Daniels, D.; Neal, M. \& Swoboda, S. M. Can mobile technology enhance learning and change educational practice? Comput. Inform. Nurs., 35(8):375-80, 2017.

Harris, T.; Leaven, T.; Heidger, P.; Kreiter, C.; Duncan, J. \& Dick, F. Comparison of a virtual microscope laboratory to a regular microscope laboratory for teaching histology. Anat. Rec., 265(1):10-4, 2001.

Hortsch, M. Virtual biology: teaching histology in the age of Facebook. FASEB J., 27(2):411-3, 2013

Janssen, A.; Shaw, T.; Goodyear, P.; Kerfoot, B. P. \& Bryce, D. A little healthy competition: using mixed methods to pilot a team-based digital game for boosting medical student engagement with anatomy and histology content. BMC Med. Educ., 15:173, 2015.

Johnson, S.; Purkiss, J.; Holaday, L.; Selvig, D. \& Hortsch, M. Learning histology - dental and medical students' study strategies. Eur. J. Dent. Educ., 19(2):65-73, 2015.

Mattheos, N.; Stefanovic, N.; Apse, P.; Attstrom, R.; Buchanan, J.; Brown, P.; Camilleri, A.; Care, R.; Fabrikant, E.; Gundersen, S.; et al. Potential of information technology in dental education. Eur. J. Dent. Educ., 12 Suppl. 1:85-92, 2008.

Norman, G. Teaching basic science to optimize transfer. Med. Teach., 31(9):807-11, 2009.

Ruiz, J. G.; Mintzer, M. J. \& Leipzig, R. M. The impact of E-learning in medical education. Acad. Med., 81(3):207-12,2006.

Salajan, F. D. \& Mount, G. J. University of Toronto's dental school shows "new teeth": moving towards online instruction. J. Dent. Educ., 72(5):532-42, 2008.

Tayyem, R.; Qandeel, H.; Qsous, G.; Badran, D. \& Bani-Hani, K. Medical students perception of current undergraduate anatomy teaching. Int. J. Morphol., 37(3):825-9, 2019.

Weaker, F. J. \& Herbert, D. C. Transition of a dental histology course from light to virtual microscopy. J. Dent. Educ., 73(10):1213-21, 2009.

Zhang, D. \& Nunamaker, J. F. Powering E-Learning In the New Millennium: An Overview of E-Learning and Enabling Technology. Inf. Syst. Front., 5:207-18 2003.

\author{
Corresponding author: \\ Dr. Salma Abubaker Abbas Ali \\ Department of Diagnostic Dental Sciences and Oral Biology \\ College of Dentistry \\ King Khalid University \\ Abha \\ SAUDI ARABIA
}

Email sabbas@kku.edu.sa

Received: 23-10-2019

Accepted: 21-01-2020 